\title{
ANALISIS SENTIMEN PT TIKI JALUR NUGRAHA EKAKURIR (PT TIKI JNE) PADA MEDIA SOSIAL TWITTER MENGGUNAKAN MODEL FEED FORWARD NEURAL NETWORK
}

\author{
Salma Farah Aliyah", Hasbi Yasin², Suparti ${ }^{3}$, Budi Warsito ${ }^{4}$, Tatik Widiharis ${ }^{5}$ \\ ${ }^{1,2,3,4,5}$ Departemen Statistika, Fakultas Sains dan Matematika, Universitas Diponegoro \\ Email : salmafarahaliyah@gmail.com
}

\begin{abstract}
In the 2000s until now, e-commerce systems have continued to develop throughout the world and even in Indonesia. PT Tiki Jalur Nugraha Ekakurir (PT Tiki JNE) is a freight forwarding company that provides convenience for the public in carrying out online shopping activities, and shipping other goods. The large volume of shipments makes PT Tiki JNE have several problems in service that have led to several kinds of responses from users. Sentiment analysis on Twitter social media can be an option to see how PT Tiki JNE's users respond to services that have been provided. These responses are classified into positive sentiments and negative sentiments. In this research data processing is performed using text mining as the initial source of numerical data from document data which will later be classified using the Artificial Neural Network model with the Resilient Backpropagation algorithm. Data labeling is done manually and sentiment scoring. The test results show that the best model obtained is FFNN 867-7-1 by using the evaluation model 10-Fold Cross Validation to get an overall accuracy performance of $80.27 \%$, kappa accuracy of $39.13 \%$, precision of $69.04 \%$, recall of $70.56 \%$, and f-measure of $69.8 \%$ which can be interpreted that the model used is quite good. Analysis of the results using wordcloud shows the tendency of opinion sentiment categories depending on the words used in the tweet.
\end{abstract}

Keywords: PT Tiki Jalur Nugraha Ekakurir, Twitter, Text Mining, Artificial Neural Network, Resilient Backpropagation

\section{PENDAHULUAN}

PT Tiki Jalur Nugraha Ekakurir atau sebagai PT Tiki JNE adalah salah satu perusahaan jasa pengiriman barang terbesar di Indonesia saat ini. Lebih dari 150 lokasi PT Tiki JNE telah terhubungkan dengan sistem komunikasi online, dikawal oleh sistem dan akses situs informasi yang efektif serta efisien bagi konsumen dalam upaya mengetahui status terkini pengiriman paket atau dokumen [11].

Twitter merupakan salah satu media sosial yang digunakan oleh masyarakat di Indonesia maupun di berbagai negara lainnya. Sekitar $73 \%$ sampai dengan $87 \%$ pengguna internet yang membaca review secara online menyatakan bahwa review mempengaruhi mereka dalam membeli suatu produk ataupun penggunaan jasa. $81 \%$ dari pengguna internet telah melakukan riset terhadap suatu produk setidaknya sekali [10]. Berdasarkan pernyataan sebelumnya, penulis ingin meneliti bagaimana respon pengguna PT Tiki JNE terhadap pelayanannya dengan menganalisis tweet pengguna PT Tiki JNE di media sosial Twitter. Analisis sentimen pada media sosial Twitter menjadi pilihan penulis untuk melihat bagaimana respon 
konsumen yang menggunakan PT Tiki JNE terhadap pelayanan yang sudah diberikan.

Pada penelitian ini akan diklasifikasikan respon pengguna PT Tiki JNE ke dalam dua sentimen, yaitu sentimen positif dan sentimen negatif. Untuk melakukan analisis sentimen dapat menggunakan metode klasifikasi. Terdapat beberapa metode klasifikasi yang banyak digunakan, salah satunya adalah Artificial Neural Network (ANN). ANN mempunyai kelebihan dalam hal kemampuan untuk generelisasi, yang bergantung pada seberapa baik ANN meminimalkan resiko empiris dan dapat diterapkan pada yang jumlahnya besar [3]. Salah satu metode pada ANN adalah Backpropagation, yang merupakan salah satu metode pada jenis jaringan multi layer. [4].

\section{Analisis Sentimen}

Analisis sentimen merupakan studi fokus komputasi untuk mengekspresikan sikap, opini, pendapat, emosi, subjektifitas, pandangan dan penilaian seseorang yang dilihat terhadap apa yang ditulis [8]. Analisis sentimen akan mengelompokkan polaritas dari teks yang ada dalam kalimat atau dokumen untuk mengetahui pendapat yang dikemukakan dalam kalimat atau dokumen tersebut apakah bersifat positif, negatif atau netral [10].

\section{Text Mining}

Text mining merupakan terapan dari konsep data mining yang data pengolahannya berbentuk dalam teks. Text mining bertujuan untuk menemukan informasi yang tidak diketahui, sesuatu yang belum diketahui dan belum dapat ditulis [6].

\section{Text Preprocessing}

Text preprocessing adalah tahap awal pada operasi knowledge discovery dari sistem text mining yang meliputi dari beberapa proses yang diadaptasi dari pengambilan informasi dan ekstraksi informasi yang mengubah format mentah, tidak terstruktur, dan memiliki format asli menjadi terstruktur dan dapat diolah pada tahapan berikutnya [5]. Preprocessing yang akan dilakukan adalah sebagai berikut: Case folding, Removing (remove URL, unescape HTML, remove mention, remove number, remove punctuation, remove emoticon, Strip White Space), dan normalisasi kalimat.

\section{Sentiment Scoring}

Pada sentiment scoring terdapat input kamus sentiment, input boosterwords dan input kata negasi. Kamus sentimen berisi kumpulan kata yang telah diberi bobot dengan kekuatan sentimen 1 sampai dengan 5 (memiliki sentimen positif), dan -1 sampai dengan -5 (memiliki sentimen negatif) [14].

\section{Pembobotan Data}

Term Frequency-Inverse Document Frequency (TF-IDF) adalah metode yang digunakan untuk menghitung bobotan setiap kata yang telah dianalisis. Model pembobotan TF-IDF merupakan metode yang mengintegrasikan model term frequency (TF) dan inverse document frequency (IDF) [9].

\section{Artificial Neural Network (ANN)}

Artificial Neural Network atau Jaringan Syaraf Tiruan adalah suatu sistem yang memiliki kemiripan dengan jaringan syaraf makhluk hidup dalam memproses informasi.

\section{Backpropagation}

Backpropagation merupakan salah satu metode pada jenis jaringan multi layer yang melatih jaringan agar seimbang antara kemampuan jaringan untuk mengenali pola yang digunakan selama pelatihan serta kemampuan jaringan untuk memberikan respon yang benar terhadap pola masukan yang serupa (tetapi tidak sama) dengan pola yang dipakai selama pelatihan. Metode ini mampu menangani pola-pola kompleks untuk medapatkan model yang optimal [4]. 
Resilient Backpropagation

Algortima Resilient Backpropagation atau Rprop merupakan hasil pengembangan dari algoritma backpropagation. Perubahan bobot pada backpropagation dipengaruhi oleh learning rate (laju pembelajaran) dan tergantung dari kemiringan kurva error $\left(\frac{\partial E}{\partial w_{i j}}\right)$. Semakin kecil learning rate maka proses pembelajaran semakin lama, sedangkan semakin besar learning rate maka nilai bobot akan jauh dari bobot minimum [2]. Masalah tersebut dapat diatasi dalam Rprop dengan cara membagi arah dan perubahan bobot menjadi dua bagian berbeda. Algoritma ini menggunakan tanda (positif atau negatif) dari gradient untuk menunjukkan arah penyesuaian bobot. Sedangkan ukuran perubahan bobot ditentukan dengan nilai pengesuaian $\left(\Delta_{0}\right)[12]$.

Evaluasi sistem diperlukan untuk suatu proses klasifikasi atau prediksi. Sebuah sistem klasifikasi harus dinilai performanya agar dapat mengukur tingkat akurasi dari prediksi klasifikasi yang dihasilkan. Akurasi merupakan bagian penting pada akhir suatu pengolahan untuk mendapatkan jangkauan yang mendekati keadaan yang sebenarnya. Nilai akurasi biasanya muncul bersamaan dengan presisi sebagai penguatan bahwa keadaan suatu model yang didapatkan menggambarkan keseragaman [7].

\section{METODOLOGI PENELITIAN Jenis dan Sumber Data}

Data yang digunakan merupakan data kualitatif berupa tweets dari pengguna media sosial Twitter. Extrating tweets dilakukan pada tanggal 25 Maret 2020 dengan kata kunci "JNE" dan kategori tweets berbahasa Indonesia sebanyak 5.000 tweets. Data yang diperoleh merupakan respon tentang JNE pada tanggal 18-25 Maret 2020. Data hasil extrating tweets tersebut dilakukan deteksi duplikat sehingga menjadi 4.030 tweets. Dari 4.030 tweets tersebut dipilih 1.500 tweets terbaru yang akan digunakan pada penelitian ini. Data 1.500 tweets tersebut merupakan respon tentang JNE pada tanggal 22-25 Maret 2020.

\section{Teknik Pengolahan Data}

Analisis data pada penelitian ini dilakukan dengan bantuan software RStudio 1.2.5033 dan Microsoft Excel 2016. Adapun langkah-langkah analisis yang dilakukan adalah sebagai berikut:

1. Extracting tweets: mengambil 5.000 tweets di media sosial Twitter dengan ketentuan tweets berbahasa Indonesia serta menghilangkan data duplikat hasil dari retweet maupun like. Kemudian dipilih 1500 tweets terbaru untuk proses klasifikasi.

2. Pre-Processing data: Sebelum digunakan perlu melakukan preprocessing pada data. Pre-processing yang dilakukan antara lain adalah case folding, remove URL, unescape HTML, remove mention, remove number, remove punctuation, remove emoticon, strip white space, dan normalisasi kalimat.

3. Pelabelan data dengan sentiment scoring dan manual: melakukan pelabelan data menjadi label positif atau negatif dengan menggunakan sentiment scoring dan secara manual.

4. Feature selection: stopwords removal dan tokenizing.

5. Pembobotan dokumen dengan TFIDF.

6. Membangun model Feed Forward Neural Network menggunakan algoritma Resilient Backpropagation dengan langkah-langkah menggunakan empat tahapan pokok yaitu inisialisasi bobot, feedforward, backpropagation, dan penyesuaian bobot. 
7. Menghitung evaluasi model klasifikasi berdasarkan $K$-Fold Cross Validation dan Confusion Matrix.

8. Pemilihan model terbaik dengan melihat tingkat akurasi berdasarkan Confusion Matrix

9. Visualisasi hasil data menggunakan wordcloud.

\section{ANALISIS DAN PEMBAHASAN \\ Extracting Tweets}

Dilakukan Extracting tweets bertujuan untuk mengumpulan data teks dari aplikasi Twitter dengan menggunakan Twitter API. Untuk melakukan extracting tweets dibutuhkan empat kode akses, yaitu API Key, API Secret, Access Token, and Access Token Secret. Kode-kode tersebut diperoleh setelah mendaftarkan akun Twitter pada https://developer.twitter.com/en/apps.

\section{Pre-Processing Data}

Proses ini merupakan tahap pengambilan data dan ekstraksi data yang mengubah format asli dan tidak terstruktur menjadi terstruktur agar dapat diolah untuk tahapan berikutnya.

\section{Case Folding}

Case folding adalah tahapan mengubah semua huruf besar atau kapital pada data twitter menjadi huruf kecil semua (lowercase).

\section{Removing}

Removing dilakukan dengan maksud menghapus semua karakter pada data twitter karena karakter dan tanda baca tersebut tidak dibutuhkan dan dapat mengganggu nilai term pada saat proses klasifikasi.

\section{Remove URL}

Remove URL akan menghapus link URL (Uniform Resource Locator) yang terdapat pada data twitter. Link URL biasanya mengandung kata "http://".

\section{Unescape HTML}

Unescape HTML akan menghapus file HTML dan menghapus jejak karakter yang dianggap sebagai markup language..

3. Remove Mention

Remove Mention akan menghilangkan kata yang mengandung simbol “@” pada bagian depan sebelum subjek yang berarti menyebutkan username pengguna twitter lain.

\section{Remove Number}

Remove number akan menghapus angka yang terdapat pada data twitter karena angka tidak menunjukkan suatu perasaan.

\section{Remove punctuation}

Remove punctuation akan menghapus tanda baca yang ada pada data twitter. Karena penelitian ini hanya mengklasifikasikan data teks, maka selain karakter alphabet akan dihapus dari data twitter.

\section{Remove Emoticon}

Remove emoticon akan menghapus emoticon. Karena emoticon yang terbaca pada dokumen tersusun dari tanda baca, maka emoticon sudah otomatis terhapus saat remove punctuation.

\section{Strip White Space}

Strip White Space akan menghapus spasi yang berlebih pada data twitter.

8. Normalisasi Kalimat

Data twitter yang digunakan pada penelitian ini terdapat banyak kata-kata bahasa Indonesia yang tidak baku, kesalahan ketik, singkatan, bahasa lokal maupun bahasa gaul yang bermacammacam. Kamus normalisasi kalimat dibuat secara manual di notepad sebanyak 1798 kata.

\section{Pelabelan Data Secara Manual}

Berdasarkan hasil crawling 1500 tweets teratas yang membicarakan JNE diperoleh sentimen positif sebanyak 1104 tweets dan sentimen negatif sebanyak 396 tweets. 


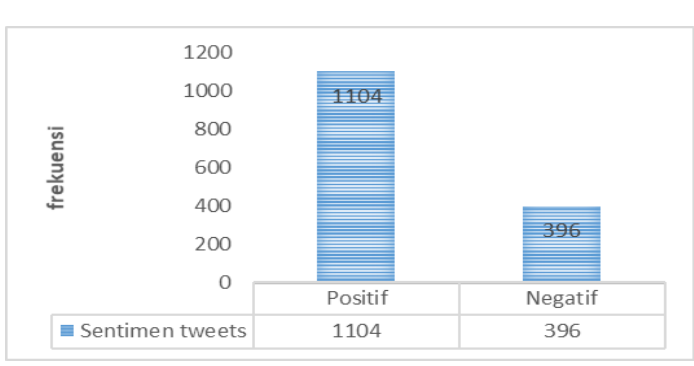

Gambar 1. Histogram Pelabelan Data Secara Manual

Sentimen negatif yang diberikan oleh pengguna terhadap JNE adalah mengenai kekecewaan terhadap pelayanan JNE yang merugikan pengguna seperti barang atau paket yang dikirimkan hilang, belum sampai, atau rusak. Dilihat dari banyaknya pengguna yang memberikan sentimen positif terhadap JNE, menunjukan bahwa JNE telah mampu memuaskan pengguna dalam pelayanan-pelayanan yang telah diberikan.

\section{Pelabelan Data dengan Sentiment Scoring}

Pelabelan data dengan sentiment scoring menggunakan tiga kamus yang disimpan dalam notepad yaitu kamus sentimen, boosterwords, dan negasi. Berdasarkan ketiga kamus tersebut, setiap tweets yang ada pada dokumen teks dihitung skornya dengan cara menjumlahkannya dengan ketentuan sebagai berikut:

1. Setiap kata pada tweets yang terdapat pada kamus sentimen akan mendapat skor sesuai dengan yang ada pada kamus sentimen, jika kata tersebut tidak terdapat pada kamus sentimen akan mendapat skor 0 .

2. Setiap kata pada tweets yang terdapat kata negasi pada kata sebelumnya akan mendapatkan skor yang berlawanan pada kamus sentimen. Contoh: kata "lengkap" pada suatu tweets akan mendapat skor +4 , jika sebelum kata "lengkap" terdapat kata negasi "tidak" maka skor yang diperoleh adalah -4 .
3. Jika suatu kata yang terdapat pada kamus sentimen bernilai > 0 yang diikuti kata boosterwords pada kata sebelumnya atau kata sesudahnya, maka skor kata sentimen ditambah skor kata boosterwords. Contoh: kata "kurang sopan" pada suatu tweets. Kata "sopan" akan mendapat skor +4 , dan kata "kurang" pada boosterwords nilai skornya -2 . Maka skor yang diperoleh dari kata "kurang sopan" adalah (+4) ditambah (-2) menjadi +2 .

4. Jika suatu kata yang terdapat pada kamus sentimen bernilai < 0 yang diikuti kata boosterwords pada kata sebelumnya atau kata sesudahnya, maka skor kata sentimen dikurang skor kata boosterwords. Contoh: kata "sedih banget" pada suatu tweets. Kata "sedih" akan mendapat skor -3, dan kata "banget" pada boosterwords nilai skornya +1 . Maka skor yang diperoleh dari kata "sedih banget" adalah (-3) dikurang (+1) menjadi -4 .

Setiap tweets diberi label positif jika skor akhir yang diperoleh $\geq 0$, dan diberi label negatif jika skor akhir yang diperoleh $<0$. Berdasarkan pelabelan data yang telah dilakukan dengan sentiment scoring, diperoleh tweets yang berlabel positif sebanyak 1179, sedangkan tweets yang berlabel negatif sebanyak 321.

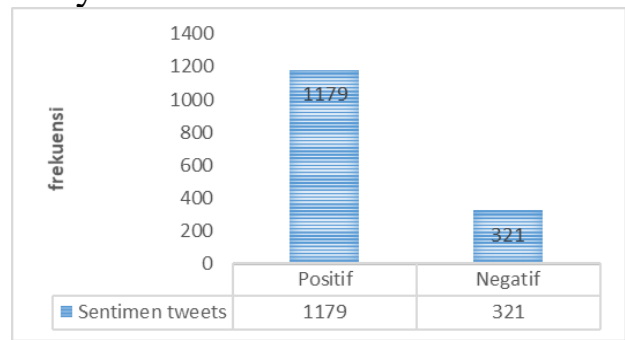

Gambar 2. Histogram Pelabelan Data dengan Sentiment Scoring

Sentiment scoring memberikan banyak kesalahan dalam melakukan pelabelan data. Setelah dilakukan pelabelan data secara manual pada 1500 tweets terdapat 75 tweets yang salah dalam pelabelan, artinya sebesar $5 \%$ tweets mendapat label yang tidak tepat. 


\section{Feature Selection}

Tahapan ini dilakukan untuk mengurangi dimensi dari sebuah data twitter dengan menghapus kata-kata yang tidak relevan sehingga proses pengelompokan lebih efektif dan akurat. 1. Stopwords Removal

Stopwords yang digunakan pada penelitian ini berjumlah 684 kata. Term yang terbentuk dari 1500 data sebanyak 2663 term. Setelah diproses dengan menggunakan TF IDF untuk mendapatkan bobot setiap term, dilakukan proses seleksi fitur untuk variable kata atau term yang dinilai kurang mempengaruhi dalam proses klasifikasi. Term yang dihilangkan merupakan term yang tidak memiliki arti penting yang ada pada file stopwords serta term yang hanya memiliki bobot dari setiap pencocokan dokumen kurang dari 2 kali kemunculan. Setelah melalui proses filtering stopwords, term yang terbentuk sebanyak 867 term sebagai variabelnya dari 1500 tweets.

\section{Tokenizing}

Pada proses Tokenizing dilakukan pemotongan dokumen menjadi bagianbagian kata yang disebut token. Spasi digunakan untuk memisahkan antar kata tersebut. Gambar 6 merupakan tokentoken dari proses tokenizing yang terbentuk setelah dilakukan filtering stopwords.

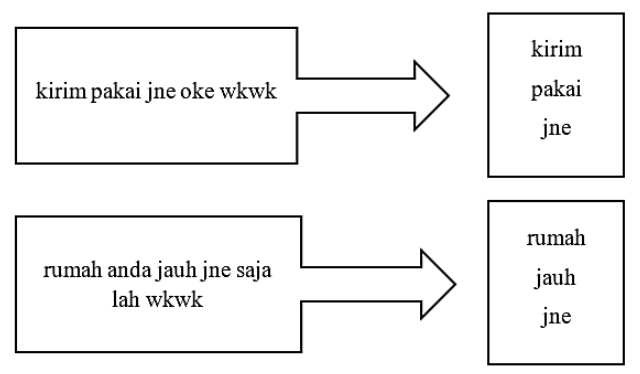

Gambar 3. Proses Filtering Stopwords dan Tokenizing

\section{Pembobotan Data}

Pembobotan kata yang digunakan pada penelitian ini adalah Term Frequency-Inverse Document Frequency (TF-IDF). Pembobotan data akan digunakan untuk membangun model klasifikasi.

Tabel 1. Pembobotan dengan Term FrequencyInverse Document Frequency

\begin{tabular}{c|ccccc}
\hline & Admin & barang & kasih & $\ldots$ & yes \\
\hline $\begin{array}{c}\text { Tweet } \\
\text { ke-1 }\end{array}$ & 0 & 0 & 2,200 & $\ldots$ & 0 \\
$\begin{array}{c}\text { Tweet } \\
\text { ke-2 } \\
\vdots\end{array}$ & 0,473 & 0,511 & 0 & $\ldots$ & 0 \\
$\begin{array}{c}\text { Tweet } \\
\text { ke- } \\
\mathbf{1 5 0 0}\end{array}$ & $\vdots$ & $\vdots$ & $\vdots$ & $\ddots$ & $\vdots$ \\
\hline
\end{tabular}

\section{Data Training dan Data Testing}

Klasifikasi Feed Forward Neural Network dengan algortima Resilient Backpropagation menggunakan data training untuk membentuk model klasifikasi, model yang terbentuk akan digunakan sebagai prediksi kelas data baru yang belum pernah ada sebelumnya. Data training dan data testing yang digunakan adalah data hasil dari pelabelan kelas dengan sentiment scoring. Data dibagi menjadi dua kelompok yaitu data menggunakan evaluasi model 5-fold cross validation dengan perbandingan data training dan data testing yaitu 80\%:20\%, dan data menggunakan evaluasi model 10-fold cross validation dengan perbandingan data training dan data testing yaitu 90\%:10\%.

Tabel 2. Proporsi Jumlah Data Twitter menggunakan 5-fold cross validation

\begin{tabular}{c|c}
\hline & Data Twitter \\
\hline Data Training & 1200 \\
Data Testing & 300 \\
\hline Jumlah & 1500 \\
\hline
\end{tabular}


Tabel 3. Proporsi Kelas Sentimen menggunakan 10-fold cross validation

\begin{tabular}{c|c}
\hline & Data Twitter \\
\hline Data Training & 1350 \\
Data Testing & 150 \\
\hline Jumlah & 1500 \\
\hline
\end{tabular}

\section{Klasifikasi Artificial Neural Network (ANN)}

Pada penelitian ini menggunakan model Feed Forward Neural Network (FFNN) dengan algoritma resilient backpropagation memunculkan output berupa bobot bobot pada setiap lapisan, nilai sum square error, dan maksimal iterasi pada saat proses training dilakukan untuk setiap proses pengelompokan data tweet terhadap sentimennya. Iterasi berhenti ketika nilai MSE training mendekati threshold yang sudah ditentukan yaitu 0,01. Masingmasing dari setiap proses training, baik pada kelompok pertama maupun kelompok kedua memasukan batas iterasi maksimum sebanyak 10000 kali iterasi. Selain itu uji coba dilakukan pada jumlah node hidden untuk mencari model terbaik dengan nilai akurasi yang paling tinggi.

\section{Pengujian Jumlah Node Hidden pada Hidden Layer}

Uji coba dilakukan dengan menggunakan 1 hidden layer dengan jumlah node yang diuji coba sebanyak 1 sampai 10 node hidden.

a) Data menggunakan 5-fold cross validation

Perbandingan hasil dari pengujian menggunakan 1 hidden layer dengan jumlah node hidden sebanyak 1 sampai 10 node pada data menggunakan 5-fold cross validation dapat dilihat pada tabel.
Tabel 4. Uji Coba Jumlah Node Hidden pada Data Menggunakan 5-Fold Cross Validation

\begin{tabular}{|c|c|c|c|}
\hline & $\begin{array}{c}\text { Jumlah } \\
\text { Node }\end{array}$ & $\begin{array}{c}\text { Maksimal } \\
\text { Iterasi }\end{array}$ & SSE \\
\hline \multirow{10}{*}{ 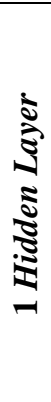 } & 1 & 270 & 11,214 \\
\hline & 2 & 375 & 6,832 \\
\hline & 3 & 163 & 5,926 \\
\hline & 4 & 109 & 5,306 \\
\hline & 5 & 402 & 5,176 \\
\hline & 6 & 78 & 5,159 \\
\hline & 7 & 197 & 5,407 \\
\hline & 8 & 180 & 4,659 \\
\hline & 9 & 82 & 4,663 \\
\hline & 10 & 174 & 4,663 \\
\hline
\end{tabular}

Terlihat bahwa jumlah node hidden yang memiliki nilai SSE paling kecil adalah 8 node yaitu sebesar 4,659. Maka model yang diambil pada data menggunakan 5-fold cross validation yaitu 1 hidden layer dengan 8 node hidden.

b) Data menggunakan 10-fold cross validation

Perbandingan hasil dari pengujian menggunakan 1 hidden layer dengan jumlah node hidden sebanyak 1 sampai 10 node pada data menggunakan 10-fold cross validation dapat dilihat pada tabel.

Tabel 5. Uji Coba Jumlah Node Hidden pada Data Menggunakan 10-Fold Cross Validation

\begin{tabular}{|c|c|c|c|}
\hline & $\begin{array}{c}\text { Jumlah } \\
\text { Node }\end{array}$ & $\begin{array}{l}\text { Maksimal } \\
\text { Iterasi }\end{array}$ & SSE \\
\hline \multirow{10}{*}{ 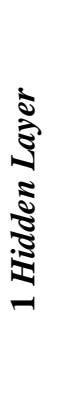 } & 1 & 173 & 14,58 \\
\hline & 2 & 214 & 7,474 \\
\hline & 3 & 236 & 7,759 \\
\hline & 4 & 291 & 6,695 \\
\hline & 5 & 173 & 7,113 \\
\hline & 6 & 481 & 5,663 \\
\hline & 7 & 124 & 5,421 \\
\hline & 8 & 202 & 5,93 \\
\hline & 9 & 76 & 5,92 \\
\hline & 10 & 74 & 5,91 \\
\hline
\end{tabular}

Terlihat bahwa jumlah node hidden yang memiliki nilai SSE paling kecil adalah 7 node yaitu sebesar 5,421. Maka model yang diambil pada data menggunakan 5-fold cross validation yaitu 1 hidden layer dengan 7 node 
hidden.

\section{Hasil Uji Node Hidden untuk Data Testing}

Kelas pada data testing belum diketahui sebelumnya. Kelas akan diketahui dengan menggunakan model yang terbentuk pada data training.

a) Data menggunakan 5-fold cross validation

Model yang dihasilkan pada uji node hidden yaitu 1 hidden layer dengan 8 node hidden. Performansi tiap fold untuk data testing pada data menggunakan 5fold cross validation dapat dilihat pada tabel.

Tabel 6. Performansi Tiap Fold untuk Data Testing pada 5-Fold Cross Validation

\begin{tabular}{c|rrrrr}
\hline $\begin{array}{c}\text { Fold } \\
\text { ke- }\end{array}$ & $\begin{array}{c}\text { Akurasi } \\
\text { Total }\end{array}$ & $\begin{array}{c}\text { Akurasi } \\
\text { Kappa }\end{array}$ & Recall & Precision & $\begin{array}{c}\boldsymbol{F} \text { - } \\
\text { Measure }\end{array}$ \\
\hline 1 & $80 \%$ & $35,32 \%$ & $69,98 \%$ & $66,09 \%$ & $68,04 \%$ \\
2 & $80,33 \%$ & $41,09 \%$ & $71,17 \%$ & $69,99 \%$ & $70,58 \%$ \\
3 & $78,67 \%$ & $35,72 \%$ & $67,46 \%$ & $68,3 \%$ & $67,88 \%$ \\
$\mathbf{4}$ & $\mathbf{8 1 , 3 3 \%}$ & $\mathbf{3 6 , 8 8 \%}$ & $\mathbf{6 9 , 9 6 \%}$ & $\mathbf{6 7 , 2 7 \%}$ & $\mathbf{6 8 , 6 1 \%}$ \\
5 & $79,33 \%$ & $32,9 \%$ & $71,04 \%$ & $64,16 \%$ & $67,6 \%$ \\
\hline $\begin{array}{c}\text { Rata- } \\
\text { rata }\end{array}$ & $\mathbf{7 9 , 9 3 \%}$ & $\mathbf{3 6 , 3 8 \%}$ & $\mathbf{6 9 , 9 2 \%}$ & $\mathbf{6 7 , 1 6 \%}$ & $\mathbf{6 8 , 5 4 \%}$ \\
\hline
\end{tabular}

Terlihat bahwa hasil ketepatan klasifikasi menggunakan 1 hidden layer dengan 8 node hidden didapatkan nilai rata-rata 5 fold untuk akurasi total, akurasi kappa, recall, precision, dan $f$ measure sebesar 79,93\%, 36,38\%, $69,92 \%, \quad 67,16 \%$, dan 68,54\%. Pemilihan fold terbaik menggunakan akurasi total sebagai pembanding utama, maka didapatkan nilai akurasi yang paling tinggi adalah $81,33 \%$ yaitu pada fold ke 4. Diambil fold ke 4 untuk melihat hasil dari confusion matrix yang dapat dilihat pada Tabel 7 .

Tabel 7. Confusion Matrix pada Data Menggunakan 5-Fold Cross Validation

\begin{tabular}{l|l|l|l|l}
\hline \multicolumn{2}{l|}{} & \multicolumn{2}{l|}{$\begin{array}{l}\text { Kelas } \\
\text { Prediksi }\end{array}$} & \multirow{2}{*}{ Jumlah } \\
\cline { 3 - 4 } \multicolumn{2}{l|}{} & Positif & Negatif & \\
\hline Kelas & Positif & 218 & 23 & 241 \\
Aktual & Negatif & 33 & 26 & 59 \\
\hline Jumlah & 251 & 49 & 300 \\
\hline
\end{tabular}

b) Data menggunakan 10-fold cross validation

Model yang dihasilkan pada uji node hidden yaitu 1 hidden layer dengan 7 node hidden. Performansi tiap fold untuk data testing pada data menggunakan 10fold cross validation dapat dilihat pada tabel.

Tabel 8. Performansi Tiap Fold untuk Data Testing pada 10-Fold Cross Validation

\begin{tabular}{c|rrrrr}
\hline $\begin{array}{c}\text { Fold } \\
\text { ke- }\end{array}$ & $\begin{array}{c}\text { Akurasi } \\
\text { Total }\end{array}$ & $\begin{array}{c}\text { Akurasi } \\
\text { Kappa }\end{array}$ & Recall & Precision & $\begin{array}{c}\boldsymbol{F} \text { - } \\
\text { Measure }\end{array}$ \\
\hline 1 & $80 \%$ & $39,02 \%$ & $70 \%$ & $69,07 \%$ & $69,54 \%$ \\
2 & $74,67 \%$ & $34,23 \%$ & $66,29 \%$ & $67,74 \%$ & $67,01 \%$ \\
3 & $81,33 \%$ & $38,54 \%$ & $68,77 \%$ & $69,83 \%$ & $69,3 \%$ \\
4 & $80,67 \%$ & $37,23 \%$ & $67,92 \%$ & $69,42 \%$ & $68,67 \%$ \\
5 & $76 \%$ & $21,78 \%$ & $63,35 \%$ & $59,54 \%$ & $61,44 \%$ \\
6 & $83,33 \%$ & $43,44 \%$ & $77,69 \%$ & $68,65 \%$ & $73,17 \%$ \\
7 & $81,33 \%$ & $38,54 \%$ & $69,83 \%$ & $68,77 \%$ & $69,3 \%$ \\
8 & $84 \%$ & $54,36 \%$ & $77,18 \%$ & $77,19 \%$ & $77,18 \%$ \\
$\mathbf{9}$ & $\mathbf{8 4 , 6 7 \%}$ & $\mathbf{5 2 , 7 \%}$ & $\mathbf{7 7 , 3 9 \%}$ & $\mathbf{7 5 , 4 6 \%}$ & $\mathbf{7 6 , 4 2 \%}$ \\
10 & $76,67 \%$ & $31,48 \%$ & $67,18 \%$ & $64,7 \%$ & $65,94 \%$ \\
\hline $\begin{array}{c}\text { Rata- } \\
\text { rata }\end{array}$ & $\mathbf{8 0 , 2 7 \%}$ & $\mathbf{3 9 , 1 3 \%}$ & $\mathbf{7 0 , 5 6 \%}$ & $\mathbf{6 9 , 0 4 \%}$ & $\mathbf{6 9 , 8 \%}$ \\
\hline \multicolumn{7}{|c}{} \\
\hline
\end{tabular}

Terlihat bahwa hasil ketepatan klasifikasi menggunakan 1 hidden layer dengan 7 node hidden didapatkan nilai rata-rata 10 fold untuk akurasi total, akurasi kappa, recall, precision, dan $f$ measure sebesar 80,27\%, 39,13\%, $70,56 \%, 69,04 \%$, dan $69,8 \%$. Pemilihan fold terbaik menggunakan akurasi total sebagai pembanding utama, maka didapatkan nilai akurasi yang paling tinggi adalah $84,67 \%$ yaitu pada fold ke 9. Diambil fold ke 9 untuk melihat hasil dari confusion matrix yang dapat dilihat pada Tabel 9.

Tabel 9. Confusion Matrix pada Data Menggunakan 10-Fold Cross Validation

\begin{tabular}{c|c|c|c|c}
\hline \multicolumn{2}{c|}{} & \multicolumn{2}{c}{ Kelas Prediksi } & \multirow{2}{*}{ Jumlah } \\
\cline { 3 - 4 } \multicolumn{2}{c|}{} & Positif & Negatif & \\
\hline $\begin{array}{c}\text { Kelas } \\
\text { Aktual }\end{array}$ & Positif & 108 & 10 & 118 \\
\hline \multicolumn{2}{c}{ Jumlah } & 121 & 29 & 150 \\
\hline
\end{tabular}

\section{Hasil Model Klasifikasi}

Setelah didapatkan hasil ketepatan klasifikasi pada kedua kelompok maka 
selanjutnya adalah membandingkan hasil. Perbandingan antara kedua kelompok berdasarkan akurasi total, akurasi kappa, recall, presicion, dan $f$ measure dapat dilihat pada tabel.

Tabel 10. Perbandingan Hasil Ketepatan Klasifikasi

\begin{tabular}{cccccc}
\hline & $\begin{array}{c}\text { Akurasi } \\
\text { Total }\end{array}$ & $\begin{array}{c}\text { Akurasi } \\
\text { Kappa }\end{array}$ & Recall & Precision & $\begin{array}{c}\text { F- } \\
\text { Measure }\end{array}$ \\
\hline 5-Fold & $79,93 \%$ & $36,38 \%$ & $69,92 \%$ & $67,16 \%$ & $68,54 \%$ \\
10-Fold & $80,27 \%$ & $39,13 \%$ & $70,56 \%$ & $69,04 \%$ & $69,8 \%$ \\
\hline
\end{tabular}

Terlihat bahwa dari hasil pengukuran performansi hasil dari data menggunakan evaluasi model 10-fold cross validation lebih baik daripada hasil dari data menggunakan evaluasi model 5-fold cross validation. Sehingga model yang didapat untuk klasifikasi data twitter terhadap sentimen menggunakan Feed Forward Neural Network adalah:

1. Pembagian data training dan data testing yaitu $90 \%: 10 \%$

2. Jumlah input : 867 node

3. Jumlah hidden layer : 1 dengan 7 node hidden

4. Evaluasi model menggunakan 10-fold cross validation

Secara visual, arsitektur model jaringan dapat diilustrasikan pada gambar dibawah.

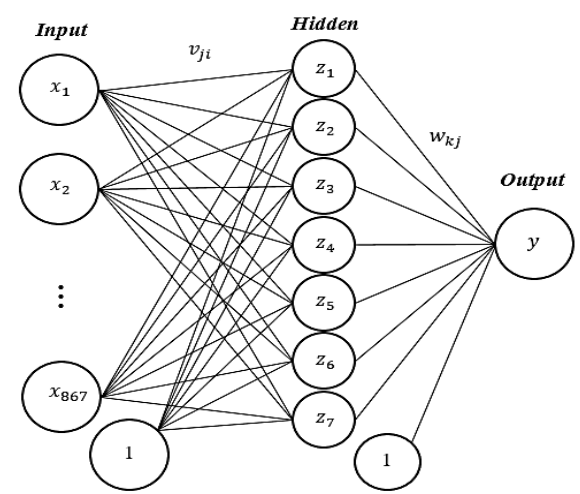

Gambar 4. Arsitektur Jaringan Model Terbaik

\section{Analisis dan Visualisasi Hasil}

Analisis dari hasil penelitian ini dapat dilakukan melalui visualisasi dengan menggunakan grafik wordcould dengan maksimal kata yang dimunculkan adalah 60 kata dari frekuensi kemunculan tertinggi. Karena pada penelitian ini menggunakan dua kategori sentimen positif dan negatif, maka pada Gambar 5 menampilkan wordcould untuk frekuensi data positif dan Gambar 6 menampilkan frekuensi data negatif.

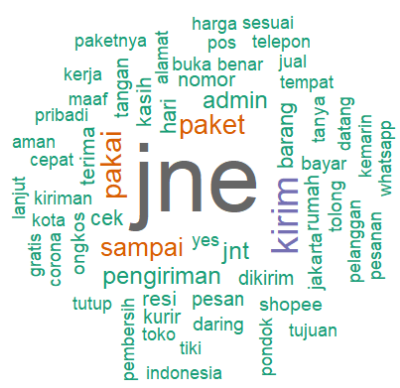

Gambar 5. Wordcloud Data pada Kategori

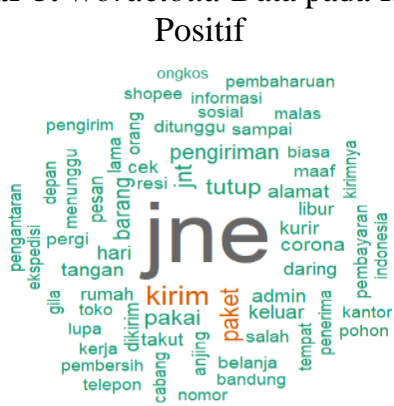

Gambar 6. Wordcloud Data pada Kategori Negatif

\section{KESIMPULAN}

Berdasarkan analisis dan pembahasan terhadap sentimen pada JNE di Twitter didapatkan beberapa kesimpulan sebagai berikut:

1. Artificial neural network berperan dalam melakukan klasifikasi opini tentang pelayanan JNE dari sentimen data tweet pada twitter. Proses ekstraksi dokumen menggunakan metode text mining untuk memperoleh pola inputan yang terstruktur berdasarkan sejumlah data yang dimiliki untuk diklasifikasi sentimennya.

2. Membangun model klasifikasi sentimen tweet tentang JNE menggunakan model Feed Forward Neural Network dengan algotirma resilient backpropagation dapat dilakukan berdasarkan uji coba jumlah node hidden, dan pembagian data training-testing dari evaluasi model $k$-fold cross validation. Uji 
coba sistem menghasilkan model arsitektur dengan jumlah input 867 node, 1 hidden layer dengan jumlah node hidden 7, pembagian data sebanyak $90 \%$ untuk data training dan $10 \%$ untuk testing, menggunakan evaluasi model 10-fold cross validation. Model dikatakan cukup baik karena memperoleh performa akurasi keseluruhan sebesar 80,27\%, akurasi kappa sebesar 39,13\%, presisi sebesar 69,04\%, recall sebesar $70,56 \%$, dan f-measure sebesar $69,8 \%$.

3. Hasil analisis menggunakan wordcould, kecendurangan kategori sentimen umumnya tergantung pada pelayanan JNE dalam sampai atau tidaknya dalam mengirimkan suatu paket ke pengguna JNE. Dengan demikian pengguna twitter yang membuat tweet opini tentang JNE berperan sebagai salah satu sumber penilaian dari baik buruknya pelayanan jasa JNE.

\section{DAFTAR PUSTAKA}

[1] Arisondang, V., Sudarsono, B. \& Prasetyo,Y. 2015. Klasifikasi Tutupan Lahan Menggunakan Metode Segmentasi Berbasis Algoritma Multiresolusi. Jurnal Geodesi Undip Volu. 4, No. 1, Hal: 9-19.

[2] Apriliyah, Mahmudy, W.F., \& Widodo, A.W. 2008. Perkiraan penjualan beban listrik menggunakan jaringan syaraf tiruan resilent backpropagation (RProp). Kursor, Vol.4, No.2, 4147.

[3] Chandani, V. 2015. Komparasi Algoritma Klasifikasi Machine Learning Dan Feature Selection pada Analisis Sentimen Review Film. Journal of Intelligent Systems, Vol.1, No.1, 56-60.
[4] Effendi, A. 2013. Penggunaan Artifial Neural Network untuk Mendeteksi Kelainan Mata Miopi pada Manusia dengan Metode Backpropagation. Universitas Islam Negeri Maulana Malik Ibrahim. Malang.

[5] 6Feldman, R. \& Sanger, J. 2007. The Text Mining Handbook. Cambridge University Press. New York.

[6] 7Gupta, V. \& Lehal, G.S. 2009. A Survey of Text Mining Techniques and Applications. Jurnal Emerging Technologies in Web Intelligence, Vol.1, No.1, 60-76

[7] 8Hanifah, I. \& Prastowo, B.N. 2016. Uji GPS Tracking dalam Skala Transportasi Antar Kota. IJEIS, Vol.6, No.2, 175-186.

[8] 11Liu, B. 2012. Sentiment Analysis and Opinion Mining. Morgan \& Claypool Publishers. San Rafael.

[9] 12Luqyana, W.A., Cholissodin, I., \& Perdana, R.S. 2018. Analisis Sentimen Cyberbullying pada Komentar Instagram dengan Metode Klasifikasi Support Vector Machine. Jurnal Pengembangan Teknologi Informasi dan Ilmu Komputer, Vol.2, No.11, 47044713.

[10] 14Pang, B. \& Lee, L. 2008. Opinion Mining and Sentiment Analysis. Foundations and Trends in Information Retrieval, Vol. 2, No.1-2, 1-135.

[11] 15PT Tiki Jalur Nugraha Ekakurir. 2015. Profil Perusahaan. www.jne.co.id/id/perusahaan. Diakses: 07 April 2020.

[12] 16Riedmiller, M. \& Braun, $H$. 1993. A Direct Adaptive method for Faster Backpropagation Learning : The RPROP Algortihm. In Proceedings of the IEEE 
International Conference on Neural Networks (ICNN),

[13] 17Salton, G. dan Buckley, C. $1988 . \quad$ Term-Weighting Approaches in Automatic Text Retrieval. Jurnal Information Processing and Management, Vol.24, No.5, 512-523.

[14] 22Wahid, D.H. \& Azhari. 2016. Peringkasan Sentimen Esktraktif di Twitter Menggunakan Hybrid TF-IDF dan Cosine Similarity. Indonesian Journal of Computing and Cybernetics Systems (IJCCS), Vol.10, No.2, 207-218. 